\title{
Strategy for chromosomal gene targeting in RecA-deficient Escherichia coli strains
}

\author{
Marianne Gamper and Peter Kast \\ Swiss Federal Institute of Technology (ETH), Zürich, Switzerland
}

BioTechniques 38:405-408 (March 2005)

Reengineering DNA by homologous recombination in Escherichia coli often depends on helper functions provided on a temporarily introduced replicon that is subsequently cured from the cells. The suicide vector $p K S S$ offers a new curing strategy. $p K S S$ specifies a variant of phenylalanyl-transfer RNA (tRNA) synthetase conferring relaxed substrate specificity towards phenylalanine analogs that results in their lethal incorporation into cellular proteins. Consequently, the presence of p-chlorophenylalanine selects for strains that have lost $\mathrm{pKSS}$. This principle, in conjunction with a plasmid-borne recA gene, was exploited for targeted chromosomal mutagenesis by double homologous recombination in RecA-negative E. coli strains. Gene replacement with a kanamycin-resistance cassette was possible in a single step by plating on kanamycin and p-chlorophenylalanine agar plates and incubating at $37^{\circ} \mathrm{C}$. The presence of the correct chromosomal mutation and the absence of the plasmid were established by several control experiments. A simple screen confirmed the desired resistance phenotype in $44 \%$ of the initially selected clones, and $75 \%$ of these had the correct genotype.

\section{INTRODUCTION}

DNA engineering in Escherichia coli by double homologous recombination is a key technology in functional genomics (1). To precisely swap genetic information between two DNA molecules in vivo, scientists have the choice between two fundamentally distinct pathways. The first pathway, termed Red/ET recombination, is mediated either by the RecE/RecT protein pair from phage $R a c$ or the Red $\alpha / \operatorname{Red} \beta$ protein pair from phage $\lambda$ (1-3). The second pathway is based on the RecA function naturally occurring in wild-type $E$. coli cells $(4,5)$.

Red/ET recombination involves transformation of linear DNA containing, for example, an antibiotic resistance marker and short (approximately $50 \mathrm{bp}$ ) DNA regions adjacent to the sequence to be targeted. Critical for its success is precise control of phage gene expression. For this reason, the phage genes reside either on a lowcopy plasmid (6) or are integrated in the bacterial chromosome $(7,8)$. To subsequently remove the phage genes, either the plasmid has to be cured, which is generally done by using a temperaturesensitive replication origin, or the integrated genes have to be eliminated by another homologous recombination. While the latter and its verification are very time-consuming, the high temperature selection requirement (up to $43^{\circ} \mathrm{C}$ ) limits plasmid curing to temperature-tolerant strains and precludes the introduction of temperature-sensitive chromosomal lesions.

RecA-dependent homologous recombination strategies also often rely on conditional plasmid replication $(4,9,10)$. For instance, a desired mutation linked to an antibiotic resistance marker on such a plasmid can be chromosomally integrated by establishing conditions incompatible with plasmid replication and simultaneously selecting for the antibiotic resistance. Frequently, a temperature-sensitive derivative of plasmid pSC101 is used (4), which again necessitates selection at elevated temperatures. Suicide plasmids with an ori $\gamma_{\mathrm{R} 6 \mathrm{~K}}$, which only replicate in strains carrying a pir gene, are also popular, but critical factors here are the copy number and the need for a $\mathrm{Pir}^{+}$host for plasmid handling (9). Other strategies to select for plasmid loss require specific mutations in a chromosomal gene, for example in polA (11) or in rpsL (12), which are often undesirable in a "designer" strain. Alternatively, linear DNA containing the reengineered chromosomal locus can be transformed into exonuclease-deficient strains in which integration into the chromosome can occur by RecA-dependent recombination (13). Drawbacks are low transformation yields (7) and the need for a time-consuming $\mathrm{P} 1$ transduction to transfer the chromosomal mutation into the desired host.

In this work, we present an alternative plasmid-curing method to introduce mutations into the $E$. coli chromosome by RecA-mediated homologous recombination, which requires neither selection at $43^{\circ} \mathrm{C}$ nor specific mutant strains. The method is based on the suicide vector pKSS (14) and allows for the straightforward one-step selection of correct clones. By temporarily providing the RecA function on the suicide replicon (15), chromosomal engineering can be accomplished even in RecA-deficient strains, the recommended choice for stable plasmid cloning.

\section{MATERIALS AND METHODS}

\section{Escherichia coli Strains, Plasmids, and Oligonucleotides}

The RecA-positive and kanamycinresistant strain AD202 (16) and RecA-negative strains KA12 (17) and KA13 (18) were described previously. Strains XL1-Blue (Stratagene, La Jolla, CA, USA) and KA13 were used for standard cloning. KA35 (this work) is $\mathrm{KA} 12 \Delta(d s b A)::$ :eo.

Oligonucleotides RECA-5' (5'GCACCGTCTGGTTTGCTTTT-3') and RECA-3' (5'-CATCAAGCCGGCTGTCATGGCATATCCTTACAA$\left.3^{\prime}\right)$ were synthesized with a Gene Assembler ${ }^{\circledR}$ Plus (Amersham Biosciences, Piscataway, NJ, USA). All other oligonucleotides were from Microsynth (Balgach, Switzerland). Plasmids pKSS (14) and pKY102 (19) were described previously. pMG205 was constructed by a four-way ligation including a fragment of pKSS, the two DNA regions ( $d s b A 1$ and $d s b A 2$ ) flanking the gene to be knocked out and the aminoglycoside 3'-phosphotransferase gene (neo) responsible for kanamycin resistance 
$\left(\mathrm{Km}^{\mathrm{R}}\right)$. The 2029-bp $d s b A 1$ fragment was obtained by PCR amplification of chromosomal KA13 DNA with primers DSBA1-5' (5'-GATAATCTAGAGTAACGGTATCATCGTTTTT- ${ }^{\prime}{ }^{\prime}$ ) and DSBA1-3' (5'-GATAATCGGCCGTCTTTTTCATGATCTACTCTCT$3^{\prime}$ ), followed by restriction digestion with $X b a \mathrm{I}$ and EagI. For the 2071-bp $d s b A 2$ fragment, primers DSBA25' (5'-GATGAATTCGGCCGTATGCTGATACAGTGAAATATCT-3') and DSBA2-3' (5'-GATGATCCGCGGCCTGCATCCCACCACCATT-3') were used followed by restriction digestion with SacII and EcoRI. PCR with primers KAN-5' (5'GATGATCGGCCGGAA A GC CACGTTGTGTCTCAA-3') and KAN-3'(5'-GATGATCGGCCGAATTCGCCTCGTGAAGAAGGTGTT-3') and chromosomal AD202 DNA as template yielded the 1208-bp neo gene fragment after restriction digestion with EagI and EcoRI. The three digested PCR products were ligated to the 4117-bp XbaI-SacII fragment from pKSS giving pMG205. Insertion of the 1332-bp SacII-NgoMIV recA gene fragment generated after PCR amplification of pKY102 with primers RECA-5' and RECA-3' into pMG205 cut with SacII and NgoMIV (9095 bp) resulted in plasmid pMG207 (Figure 1). To verify the chromosomal lesion, two primers hybridizing to chromosomal DNA outside of the segments cloned in pMG207 were used (DSBAKO-5', 5'CGGTACCACTCCACGCGGCAAA$3^{\prime}$ and DSBAKO-3', 5'-CCGGAGCGACGTGGTAAAGATGT-3').

\section{Media and Growth Conditions}

LB medium and LB agar medium were from Q-BIOgene (Montreal, Canada). YEG-Cl medium (14) containing $25 \mu \mathrm{g} / \mathrm{mL}$ kanamycin sulfate was used for direct selection. YEG-Cl $\mathrm{Km}_{25}$ agar was prepared as follows: 5 $\mathrm{g}$ yeast extract (Oxoid, Basingstoke, $\mathrm{UK}), 10 \mathrm{~g} \mathrm{NaCl}, 15 \mathrm{~g}$ agar (A-7002; Sigma, St. Louis, MO, USA), and $2 \mathrm{~g}$ D,L-p-chlorophenylalanine (13,071-0; Sigma) were autoclaved in $1 \mathrm{~L}$ ultrapurified water. Then, $20 \mathrm{~mL} 20 \%$ glucose $(\mathrm{w} / \mathrm{v})$ and $500 \mu \mathrm{L} 50 \mathrm{mg} / \mathrm{mL}$ kanamycin sulfate were added.

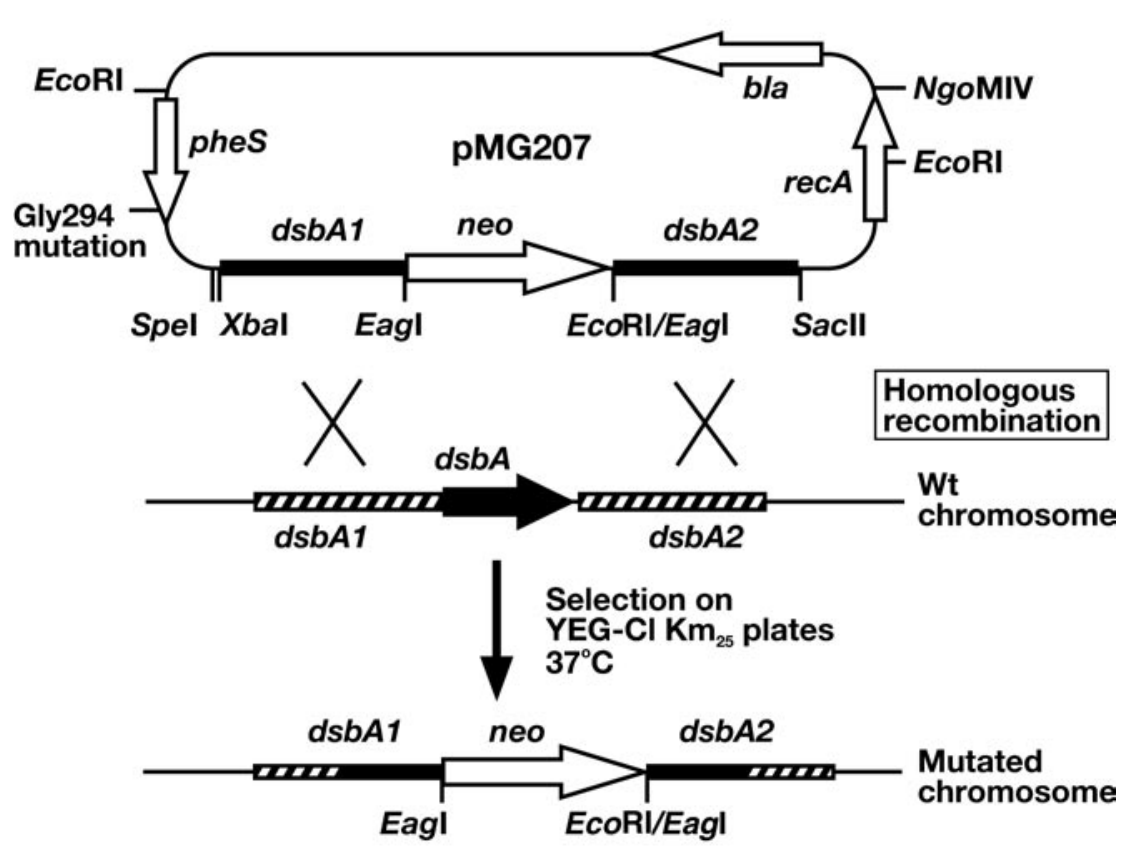

Figure 1. Double homologous recombination. The knockout plasmid pMG207 is shown with the two approximately 2.0-kb DNA regions ( $d s b A 1$ and $d s b A 2)$ flanking $d s b A$ on the chromosome and the bla (providing ampicillin resistance; $\mathrm{Ap}^{\mathrm{R}}$ ), neo, recA, and pheS Gly294 genes. Homologous recombination is symbolized by X. Relevant restriction sites are shown. The maps are not drawn to scale. Wt, wild-type.

\section{General Molecular Biological Techniques}

Restriction enzymes and T4DNA-ligase were from New England BioLabs (Beverly, MA, USA), and JumpStart ${ }^{\mathrm{TM}}$ Taq DNA polymerase was obtained from Sigma. All enzymes were used as specified by the manufacturers. $\mathrm{CaCl}_{2}$ transformation and agarose gel electrophoresis was done by standard techniques (20). Plasmid DNA was isolated by JETquick Plasmid Miniprep Spin Columns (GENOMED, Research Triangle Park, NC, USA). Chromosomal E. coli DNA was isolated from the pellet of 5-mL cultures by resuspension in $500 \mu \mathrm{L}$ G1 buffer (50 mM Tris- $\mathrm{HCl}$, pH 8.0, $10 \mathrm{mM}$ EDTA, $100 \mu \mathrm{g} / \mathrm{mL}$ RNase A), cell lysis at $4^{\circ} \mathrm{C}$ for $5 \mathrm{~min}$ after adding $20 \mu \mathrm{L}$ lysozyme $(50 \mathrm{mg} / \mathrm{mL})$ and 50 $\mu \mathrm{L} 10 \%$ sodium dodecyl sulfate, and extraction (three times) with 1 volume phenol/ $\mathrm{CHCl}_{3}$ after adding $12 \mu \mathrm{L} 5 \mathrm{M}$ $\mathrm{NaCl}$. The DNA was precipitated with 2.5 volumes $100 \%$ ethanol, washed with $70 \%$ ethanol, and dissolved in 50 $\mu \mathrm{L}$ TE (10 mM Tris-HCl, pH 8.0, $1 \mathrm{mM}$ EDTA). Analytical PCRs contained 40 ng chromosomal DNA, 25 pmol primers, $0.2 \mathrm{mM}$ dNTPs, and $2.5 \mathrm{U}$ JumpStart Taq DNA polymerase in the supplied buffer in a total volume of 50 $\mu \mathrm{L}$. Forty-five PCR cycles were run with annealing temperatures between $53^{\circ}$ and $65^{\circ} \mathrm{C}$, depending on the primer pairs.

\section{RecA Assay}

Strains harboring a functional RecA protein are capable of repairing DNA damage introduced by low doses of UV irradiation while strains lacking RecA (recA mutants) cannot survive (21). To check the RecA phenotype, cells of a fresh, medium-sized colony were resuspended in $300 \mu \mathrm{L} 1 \times \mathrm{A}$ salts $[10 \times \mathrm{A}$ salts are $105 \mathrm{~g} \mathrm{~K}_{2} \mathrm{HPO}_{4}, 45 \mathrm{~g} \mathrm{KH}_{2} \mathrm{PO}_{4}$, $10 \mathrm{~g}\left(\mathrm{NH}_{4}\right)_{2} \mathrm{SO}_{4}$, and $5 \mathrm{~g}$ sodium-citrate in $1 \mathrm{~L}$ ultrapurified water]. Three microliters of each suspension were spotted to corresponding grid positions on two identical LB plates. One of these plates was irradiated with UV light (for $3 \mathrm{~min}, 254 \mathrm{~nm}, 2 \times 6 \mathrm{~W}$ lamp, distance $60 \mathrm{~cm}$ to an open Petri dish). The conditions for the appropriate UV 
dose may vary among $E$. coli strains and need to be established with control $\mathrm{RecA}^{+}$and $\mathrm{RecA}^{-}$strains. Both LB plates were incubated in the dark for 24 h at $30^{\circ} \mathrm{C}$.

\section{RESULTS AND DISCUSSION}

Customized E. coli strain construction may require precise and stable chromosomal deletions in RecAdeficient host strains. To replace $d s b A$ encoding a periplasmic disulfide bond oxidase (22) with a $\mathrm{Km}^{\mathrm{R}}$ cassette (neo) in the $\Delta$ recA strain KA12, we have developed a new strategy that temporarily provides the $\operatorname{Rec} A$ function necessary for targeted homologous recombination. This strategy was based on the suicide vector pKSS (14), which carries a modified pheS gene, whose Ala294Gly mutation affords an $\alpha$ subunit of phenylalanyl-transfer RNA (tRNA) synthetase with relaxed substrate specificity (23). On medium containing $p$-chlorophenylalanine, a strain harboring $\mathrm{pKSS}$ cannot survive because the amino acid analog is detrimentally incorporated into cellular proteins instead of phenylalanine $(14,24)$. Consequently, selection with $p$-chlorophenylalanine and kanamycin should yield strains that have lost the plasmid (and concomitantly, the pheS and $r e c A$ genes) and have integrated the neo gene into their chromosome.

Plasmid pMG207 was assembled for the chromosomal knockout of $d s b A$ (Figure 1). Table 1 shows the timeline for the chromosomal mutagenesis. Transformants with plasmid pMG207 were grown in $\mathrm{LB} \mathrm{Km}_{25}$ liquid medium in the absence of ampicillin to allow for double homologous recombination (Figure 1) and spontaneous plasmid loss. Subsequent plating on YEG-Cl $\mathrm{Km}_{25}$ [containing $p$-chlorophenylalanine, but only little competing phenylalanine (14)] and incubation at $37^{\circ} \mathrm{C}$ for 2 days yielded strains with an integrated neo gene but lacking plasmid. The $37^{\circ} \mathrm{C}$ incubation step resulted in enhanced selection pressure for plasmid loss since we observed that $E$. coli cells harboring high-copy number plasmids with the recA gene (such as pMG207) have difficulties growing at $37^{\circ} \mathrm{C}$. As shown in Table 1, 14 of the 32 tested clones

Table 1. Protocol for Strain Construction by the Day ${ }^{a}$

\begin{tabular}{|c|c|c|}
\hline Day & Manipulation & Results \\
\hline Day 1 & $\begin{array}{l}\text { Transform KA12 with pMG } 207 \text {; select on LB } \mathrm{Ap}_{150} \\
\mathrm{Km}_{25} \text { plates, } 30^{\circ} \mathrm{C} \text {. }\end{array}$ & \\
\hline Day 2 & $\begin{array}{l}\text { Streak-out transformants to single colonies on LB } \\
\mathrm{Ap}_{150} \mathrm{Km}_{25} \text { plates; incubate overnight at } 30^{\circ} \mathrm{C} \text {. }\end{array}$ & \\
\hline Day 3 & $\begin{array}{l}\text { Inoculate } 5 \mathrm{~mL} \text { LB } \mathrm{Km}_{25} \text { liquid medium with a } \\
\text { single colony; incubate overnight at } 30^{\circ} \mathrm{C} \text {. }\end{array}$ & $\begin{array}{l}\text { Two cultures were } \\
\text { started in parallel. }\end{array}$ \\
\hline Day 4 & $\begin{array}{l}10 \times \text { and } 100 \times \text { dilution of the grown culture in } 1 \times \mathrm{A} \\
\text { salts. Plate } 100 \mu \mathrm{L} \text { of each dilution onto YEG-Cl } \\
\mathrm{Km}_{25} \text { selection plates; incubate at } 37^{\circ} \mathrm{C} \text { for } 2 \text { days. }\end{array}$ & $\begin{array}{l}\text { Plating of } 4 \times 100 \mu \mathrm{L} \\
\text { of } 10 \times \text { dilution gave } \\
47 \text { colonies. }\end{array}$ \\
\hline Day 6 & $\begin{array}{l}\text { Streak-out } 32 \text { colonies to obtain single colonies on } \\
\text { YEG-CI Km } \\
25\end{array}$ & \\
\hline Day 8 & $\begin{array}{l}\text { Spot } 32 \text { colonies (one from each purification) onto } \\
\text { LB Ap }{ }_{150} \text {, LB Km } \mathrm{Km}_{25} \text {, and LB plates (in this order). } \\
\left.\text { Useful controls: KA12 (RecA }, \mathrm{Ap}^{\mathrm{S}}, \mathrm{Km}^{\mathrm{S}}\right), \mathrm{AD} 202 \\
\left(\mathrm{RecA}^{+}, \mathrm{Ap}^{\mathrm{S}}, \mathrm{Km}^{\mathrm{R}}\right) \text {, and } \mathrm{KA} 12 / \mathrm{pMG}^{2} 07\left(\operatorname{Rec} \mathrm{A}^{+} \text {, }\right. \\
\left.\mathrm{Ap}^{\mathrm{R}}, \mathrm{Km}^{\mathrm{R}}\right) \text {; incubate for } 24 \mathrm{~h} \text { at } 30^{\circ} \mathrm{C} \text {. }\end{array}$ & $\begin{array}{l}14 \text { out of } 32 \text { colonies } \\
\text { were } \mathrm{Ap}^{\mathrm{S}} \text { and } \mathrm{Km}^{\mathrm{R}} \\
\text { (desired phenotype). }\end{array}$ \\
\hline Day 9 & $\begin{array}{l}\text { Repurify eight candidate KA35 colonies to single } \\
\text { colonies on } \mathrm{LB} \mathrm{Km_{25 }} \text { plates and incubate for } 24 \mathrm{~h} \\
\text { at } 30^{\circ} \mathrm{C} \text {. }\end{array}$ & \\
\hline Day 10 & $\begin{array}{l}\text { RecA assay of the eight candidate clones; incu- } \\
\text { bate over night at } 30^{\circ} \mathrm{C} \text {. Inoculate } 4 \times 5 \mathrm{~mL} \text { LB } \\
\text { with } \mathrm{KA} 35 \text { candidates; incubate overnight at } 30^{\circ} \mathrm{C} \text {. }\end{array}$ & $\begin{array}{l}\text { All tested } \mathrm{Ap}^{\mathrm{S}} \text { and } \mathrm{Km}^{\mathrm{R}} \\
\text { clones were RecA }\end{array}$ \\
\hline Day 11 & $\begin{array}{l}\text { Isolate chromosomal DNA of the four cultures and } \\
\text { as a control of KA12. Chromosomal PCR. }\end{array}$ & \\
\hline Day 12 & $\begin{array}{l}\text { Restriction digest of the chromosomal PCR frag- } \\
\text { ments; agarose gel analysis. }\end{array}$ & $\begin{array}{l}\text { Three of four clones had } \\
\text { the correct genotype. }\end{array}$ \\
\hline
\end{tabular}

(44\%) exhibited the desired resistance phenotype on master plates [ampicillinsensitive $\left(A p^{S}\right)$ and $K m^{R}$. In fact, these 14 clones already grew better on the YEG-Cl $\mathrm{Km}_{25}$ plates (day 6) than the 18 other ones. The false positives showed inappropriate combinations of antibiotic resistances; 10 clones were still ampicillin-resistant and $\mathrm{Km}^{\mathrm{R}}$, and some even had problems growing on LB without antibiotics. The RecA assay confirmed that all $\mathrm{Ap}^{\mathrm{S}}$ clones were also $\mathrm{RecA}^{-}$as expected, since the corresponding genes were linked on the plasmid. Chromosomal PCR (not shown) with primers annealing to $d s b A$ outside of the segments present in pMG207 further ruled out plasmid cointegrates. Restriction analysis of the PCR products confirmed the correct location of the lesion on the chromosome for three of four investigated candidates for the new $d s b A$ knockout strain KA35; the inappro- priate clone had too large an insertion. With plasmid pMG207 at hand, the entire strain construction procedure was completed within 12 days, including all verification steps (Table 1). It takes just four additional days to assemble a new customized knockout plasmid starting from pMG207 (plus two more days for plasmid verification).

In conclusion, we present here a system for targeted chromosomal mutagenesis that is complementary to the previously described methods and overcomes some of their drawbacks and limitations: (i) By provision of a recA gene on the suicide plasmid, RecA-negative precursor strains can be reengineered, including most common cloning hosts and well-established "designer" strains for directed evolution experiments $(17,25)$. (ii) Selection for $p$-chlorophenylalanine resistance directly identifies clones that have lost the suicide plasmid, making 
a high-temperature (up to $43^{\circ} \mathrm{C}$ ) incubation step, which is often harmful for $E$. coli or incompatible with the phenotype of a new chromosomal mutation, unnecessary. (iii) To cure the suicide vector, no additional chromosomal mutation is required in the host. (iv) The system is very efficient with one third of the selected clones having the correct genotype. (v) With the integration plasmid at hand, strain construction and verification takes less than 2 weeks. Furthermore, the method requires very little interaction time; except for the final PCR analysis, the daily tasks are accomplished within 1 h. (vi) Unlike other conditional plasmids in use, our knockout plasmid is a high-copy number replicon making DNA isolation and handling easier. (vii) The system is highly versatile; by exchanging the flanking regions of the targeted gene ( $d s b A l$ and $d s b A 2$; Figure 1) in pMG207, we have constructed two other chromosomal mutations with yields similar to those presented in this work. The neo gene can easily be replaced with a different antibiotic resistance cassette. If required, the resistance gene can be provided with flanking FRT or loxP sites for subsequent excision from the chromosome by a site-specific recombination step based on the well-established Flp/FRT or Cre/loxP systems, respectively $(6,10)$.

\section{ACKNOWLEDGMENTS}

We are grateful to Donald Hilvert and the ETH Zürich for their support.

\section{COMPETING INTERESTS STATEMENT}

The authors declare no competing interests.

\section{REFERENCES}

1. Muyrers, J.P.P., Y. Zhang, and A.F. Stewart. 2001. Techniques: recombinogenic engineering-new options for cloning and manipulating DNA. Trends Biochem. Sci. 26:325-331.

2.Poteete, A.R. 2001. What makes the bacteriophage $\lambda$ Red system useful for genetic engineering: molecular mechanism and biological function. FEMS Microbiol. Lett. 201:9-14.
3. Zhang, Y., J.P.P. Muyrers, J. Rientjes, and A.F. Stewart. 2003. Phage annealing proteins promote oligonucleotide-directed mutagenesis in Escherichia coli and mouse ES cells. BMC Mol. Biol. 4:(Art. No. 1).

4. Hamilton, C.M., M. Aldea, B.K. Washburn, P. Babitzke, and S.R. Kushner. 1989. New method for generating deletions and gene replacements in Escherichia coli. J. Bacteriol. 171:4617-4622.

5. Amundsen, S.K. and G.R. Smith. 2003. Interchangeable parts of the Escherichia coli recombination machinery. Cell 112:741-744.

6. Datsenko, K.A. and B.L. Wanner. 2000. One-step inactivation of chromosomal genes in Escherichia coli K-12 using PCR products. Proc. Natl. Acad. Sci. USA 97:6640-6645.

7. Murphy, K.C. 1998. Use of bacteriophage $\lambda$ recombination functions to promote gene replacement in Escherichia coli. J. Bacteriol. 180:2063-2071.

8.Yu, D., H.M. Ellis, E.-C. Lee, N.A. Jenkins, N.G. Copeland, and D.L. Court. 2000. An efficient recombination system for chromosome engineering in Escherichia coli. Proc. Natl. Acad. Sci. USA 97:5978-5983.

9.Metcalf, W.W., W. Jiang, L.L. Daniels, S.K. Kim, A. Haldimann, and B.L. Wanner. 1996. Conditionally replicative and conjugative plasmids carrying lacZ $\alpha$ for cloning, mutagenesis, and allele replacement in bacteria. Plasmid 35:1-13.

10.Palmeros, B., J. Wild, W. Szybalski, S. Le Borgne, G. Hernández-Chávez, G. Gosset, F. Valle, and F. Bolivar. 2000. A family of removable cassettes designed to obtain antibiotic-resistance-free genomic modifications of Escherichia coli and other bacteria. Gene 247:255-264.

11.Gutterson, N.I. and D.E. Koshland, Jr. 1983. Replacement and amplification of bacterial genes with sequences altered in vitro. Proc. Natl. Acad. Sci. USA 80:4894-4898.

12.Imam, A.M.A., G.P. Patrinos, M. de Krom, S. Bottardi, R.J. Janssens, E. Katsantoni, A.W.K. Wai, D.J. Sherratt, et al. 2000. Modification of human $\beta$-globin locus PAC clones by homologous recombination in Escherichia coli. Nucleic Acids Res. 28:e65.

13.Russell, C.B., D.S. Thaler, and F.W. Dahlquist. 1989. Chromosomal transformation of Escherichia coli recD strains with linearized plasmids. J. Bacteriol. 171:26092613.

14.Kast, P. 1994. pKSS-a second generation general-purpose cloning vector for efficient positive selection of recombinant clones. Gene 138:109-114.

15.Sektas, M., M. Gregorowicz, and W. Szybalski. 1999. Transient conversion to $\operatorname{Rec}^{+}$ phenotype to permit P1 transduction in any Escherichia coli recA ${ }^{-}$strains. BioTechniques 27:911-914.

16.Nakano, H., T. Yamazaki, M. Ikeda, H. Masai, S. Miyatake, and T. Saito. 1994. Purification of glutathione-S-transferase fusion proteins as a nondegraded form by using a protease-negative Escherichia coli strain, AD202. Nucleic Acids Res. 22:543-544.

17.Kast, P., M. Asif-Ullah, N. Jiang, and D. Hilvert. 1996. Exploring the active site of chorismate mutase by combinatorial muta- genesis and selection: the importance of electrostatic catalysis. Proc. Natl. Acad. Sci. USA 93:5043-5048.

18.MacBeath, G., P. Kast, and D. Hilvert. 1998. A small, thermostable, and monofunctional chorismate mutase from the archeon Methanococcus jannaschii. Biochemistry 37:10062-10073.

19.Ihara, M., Y. Oda, and K. Yamamoto. 1985. Convenient construction of strains useful for transducing recA mutations with bacteriophage P1. FEMS Microbiol. Lett. 30:33-35.

20.Sambrook, J. and D. Russell. 2001. Molecular Cloning: A Laboratory Manual 3rd ed. CSH Laboratory Press, Cold Spring Harbor, NY

21.Courcelle, J. and P.C. Hanawalt. 2003. RecA-dependent recovery of arrested DNA replication forks. Annu. Rev. Genet. 37:611646.

22.Bardwell, J.C.A., K. McGovern, and J. Beckwith. 1991. Identification of a protein required for disulfide bond formation in vivo. Cell 67:581-589.

23.Kast, P. and H. Hennecke. 1991. Amino acid substrate specificity of Escherichia coli phenylalanyl-tRNA synthetase altered by distinct mutations. J. Mol. Biol. 222:99-124.

24.Ibba, M., P. Kast, and H. Hennecke. 1994 Substrate specificity is determined by amino acid binding pocket size in Escherichia coli phenylalanyl-tRNA synthetase. Biochemistry 33:7107-7112.

25.Besenmatter, W., P. Kast, and D. Hilvert. 2004. New enzymes from combinatorial library modules. Methods Enzymol. 388:91102.

Received 7 July 2004; accepted 21 October 2004.

Address correspondence to Peter Kast, Laboratorium für Organische Chemie, ETH Hönggerberg-HCI F333, CH-8093 Zürich, Switzerland. e-mail: kast@org. chem.ethz.ch 